\title{
The role of reedbeds in secondary habitats during the migration and breeding of reed warblers
}

\author{
László Bozó
}

Received: April 21, 2020 - Revised: May 28, 2020 - Accepted: May 29, 2020

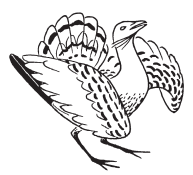

Bozó, L. 2020. The role of reedbeds in secondary habitats during the migration and breeding of reed warblers. - Ornis Hungarica 28(2): 76-91. DOI: 10.2478/orhu-2020-0006 during both breeding and migration periods. The nesting and the migration of these species have been the subject of detailed research over the past half century in the Carpathian Basin. However, these studies have focused primarily on natural habitats and large reedbeds and thus, little is known about the role of smaller habitat fragments in the migration and nesting of these species. During my work, I studied the spring and autumn migration of five passerines in a landscape dominated by agricultural land in Southeast Hungary. Field observations were carried out to survey the populations of different species between 2010-2019. To study their migration, I used the method of bird ringing between 2016-2019 in an oleaster forest and a drainage canal. I was able to determine the migration periods of the species and in autumn, to calculate the time spent in the research area based on the recaptures. In conclusion, reedbeds in secondary habitats play a similar role in the migration of the most common Acrocephalus and Locustella species as in the natural habitats in different regions of the Carpathian Basin. There are differences among species in the timing of migration, the length of time spent here, and the accumulated fat stores. As these species nest in small numbers in the area, primarily individuals from more distant populations occur here during the migration.

Keywords: Acrocephalus, agricultural lands, drainage canal, habitat conservation, Locustella, Southeast Hungary

Összefoglalás A nádasok nélkülözhetetlen élőhelyet jelentenek a különböző Acrocephalus és Locustella fajok számára a költési és vonulási időszakban egyaránt. Vonulásukat és költésüket részletesen tanulmányozták az elmúlt fél évszázadban a Kárpát-medencében, de ezek a kutatások elsősorban természetes élőhelyekre és nagy kiterjedésủ nádasokra koncentrálódtak. A fragmentált és kis kiterjedésủ, másodlagos élőhelyeken alig foglalkoztak ezen kérdések vizsgálatával. Jelen dolgozatban Délkelet-Magyarországon, egy mezőgazdasági területek által dominált tájban öt, nádasban élő énekesmadár faj tavaszi és őszi vonulási és fészkelési időszakban gyűjtött adatait dolgoztam fel. Az adatgyüjtés 2016-2019 között egy ezüstfás erdőben és egy belvízelvezető csatornában zajlott a madárgyürüzés módszerével, 2010-2019 között terepi megfigyelésekkel. A jelölés-visszafogás adatok segítségével meghatároztam a fajok vonulási időszakait, és a madarak által a területen eltöltött időt. Az eredmények szerint a másodlagos élőhelyeken található kis kiterjedésű nádasok hasonló szerepet töltenek be a nádi énekesek vonulásában, mint a Kárpát-medence más területein található természetes élőhelyek nádasai. A fajok vonulásának időzítésében, az itt töltött idő hosszában és a felhalmozott zsírraktárakban különbségek vannak. Mivel a térségben ezek a fajok csak kis számban fészkelnek, így a vonulás során elsősorban távolabbi populációk egyedei fordulnak itt elő.

Kulcsszavak: Acrocephalus, mezőgazdasági területek, belvízelvezető csatorna, Locustella, Délkelet-Magyarország

Eötvös Loránd Tudományegyetem, Állatrendszertani és Ökológiai Tanszék, 1117 Budapest, Pázmány Péter sétány 1/c,e-mail: bozolaszlo91@gmail.com 


\section{Introduction}

Reedbeds provide very important resting, feeding and nesting area for many bird species (Bíró 2007). Highly protected bird species, such as the Great Egret Ardea alba, Spoonbill Platalea leucorodia or Glossy Ibis Plegadis falcinellus breed in these habitats. They provide home not only for the large birds but also for the songbirds (Haraszthy 2013). Many of them use these habitats during migration and wintering, and they occur in different parts of the reedbeds during breeding (Csörgő 1995, Báldi \& Kisbenedek 1999, Preiszner \& Csörgő 2008). However, the extent of reedbeds across Europe is declining due to tourism and improper management. One of the many harmful interventions that reduce the area of reedbeds is the fragmentation and the lack of old reeds, which affects the populations of most of the songbirds breeding here (Haraszthy 2013). As a result, in recent times, there was a decline in the number of many species, and without proper conservation efforts, these species can easily disappear along with reedbeds. It is particularly disadvantageous for those species which only settle in old, unharvested reedbeds and those which require large, continuous patches. In contrast, certain species, such as Great Reed Warbler, does not necessarily need large, non-harvested habitats, but a small lakeside reed spot is enough for them to settle (Csörgő 1998a).

The reedbed is important not only during the breeding period but also during the migration period for many species. Habitat use, migration patterns and population changes of these species have been the subject of numerous studies in the Carpathian Basin (Gyurácz \& Csörgő 1994, Gyurácz \& Bank 1997, Csörgő et al. 1998, Gyurácz et al. 1998, Gyurácz et al. 2003, Vadász et al. 2008, Nagy et al. 2009, Czikkelyné Ágh 2014) within the framework of bird ringing programs working in reedbeds of fishponds and natural habitats.

However, reedbeds occur not only in natural but also in secondary habitats, such as at the edges of pit lakes and along inland drainage canals. Permanent water cover is not necessarily needed for reedbeds, as it can be found in dry habitats, usually in the steppes. These are the so-called dry reeds, which cause serious problems in the conservation of nature due to their prevalence against native vegetation (Haraszthy 2013).

The breeding and migration of songbirds have not yet been studied in detail in these types, although in some landscapes these are the dominant reed habitats. The southern part of Békés County is also one of these, since it is a plain covered by infusion loess, with only one stream flowing in the area (Száraz-ér) and with no natural standing water at all (Jakab \& Deli 2012). Although small reed patches can be found nearby small, artificial quarry ponds and drainage canals, the most important reedbeds can be found in lawns (Bozó 2017).

During my work, I examined the nesting population and migration of four Acrocephalus and one Locustella species associated with reedbeds. I was looking for the role of these secondary reedbeds in the breeding and migration of the studied species, with particular reference to their stopover ecology. 


\section{Material and Methods}

I carried out my research in the area of Kevermes and Lökösháza in the southern part of Békés County (Figure 1). There were two methods of sampling. For the breeding population survey, simple field observations were made on the 5000 hectares area of the two settlements. During the binocular observations, I cycled through the area. I have observation data from 439 different days between April and August from 2010 to 2019. The central areas of the surveys were the quarry ponds in Kevermes and the Turai lawn in Lökösháza, but I regularly visited all the canals and other reedbeds in other areas as well. For a detailed description of the areas, see the work of Bozó (2017). In the case of this paper, it should be emphasized that only small reed patches can be found in the quarry ponds as well as along canals. In contrast, the Turai lawn has an approx. 25 hectares of reedbeds, which, in the deeper parts of the flat, form a habitat mixed with bulrush and other swamp vegetation. Since only a part of the area is mown regularly, the reedbeds also appear in smaller or larger patches on the protected vegetation of the lawn. The data collected during the spring migration are also primarily based on field observations, but since 2012, I have been able to use occasional bird ringing data. These come from the Kevermes gravel mine. For a detailed description of the area and non-standard ringing work, see Bozó (2016). During the autumn seasons from 2016 to 2019, I was ringing in a 0.5 hectare patch of the former Pheasant station (EOV 815638 123876) with a seven-meter long and twelve pieces of twelve-meter long Japanese-type mist nets. It is a bushy area, where in addition to the dominant oleaster Elaeagnus

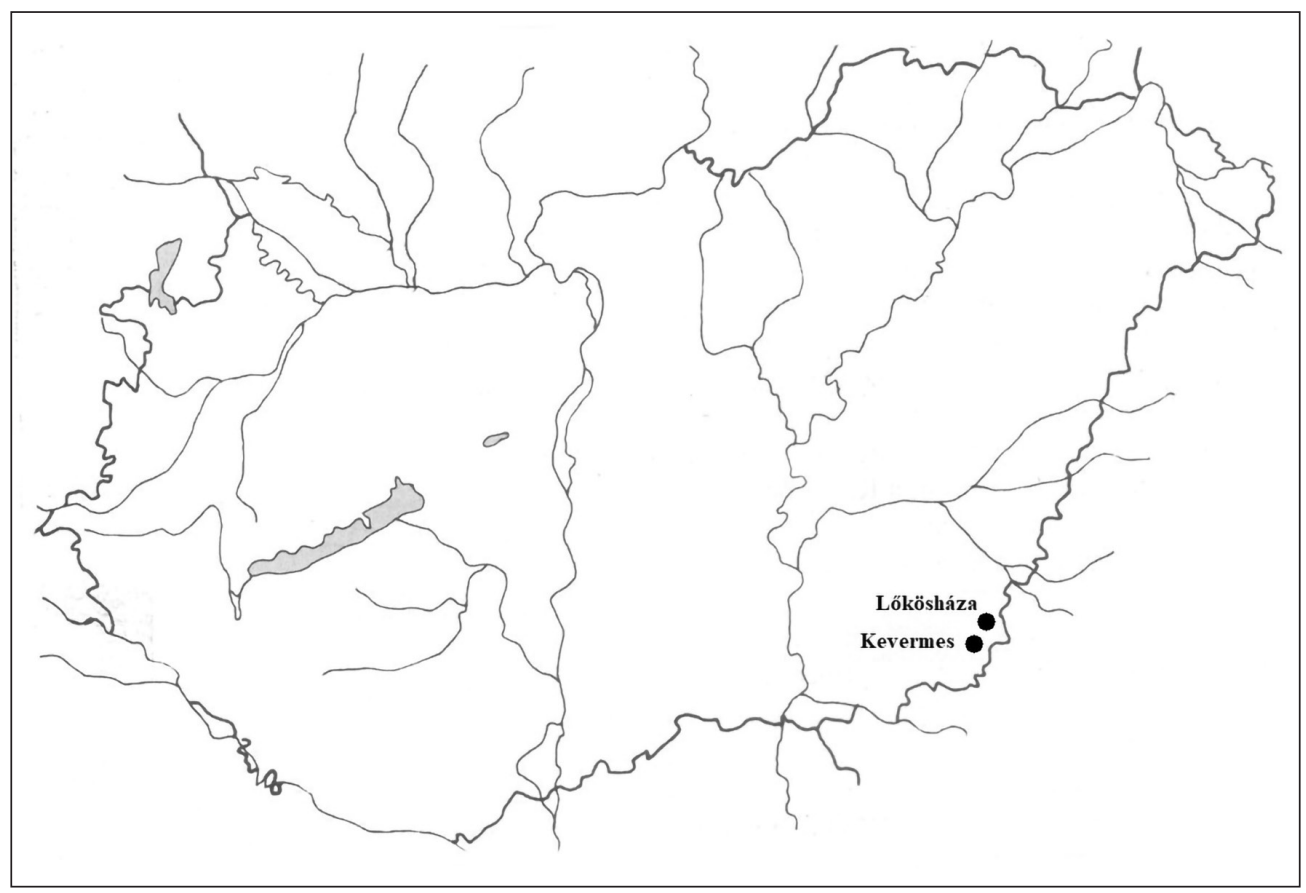

Figure 1. The location of the study area within Hungary

1.ábra A kutatási terület Magyarországon belüli elhelyezkedése 
angustifolia, some taller elms Ulmus sp., black locust Robinia pseudoacacia and wild pear Pyrus pyraster can also be found. The shrub level consisted of black elder Sambucus nigra and blackthorn Prunus spinosa, while at lower levels, blackberry Rubus caesius was common. At the edge of the forest, the vegetation was denser, with reeds and weeds. Behind the forest, there was a drainage canal with southeast-northwestern orientation (Tulkánéri canal), with young willows Salix sp. on its shores, and dense reedbed on the shore and in the riverbed. During the ringing, I collected different biometric data (wing length, subcutaneous fat, weight) according to Eck et al. (2011), I determined the age and the sex of the birds by Svensson (1992), and then released them. The work took place between the beginning of August and the end of October for two days a week (16 working hours).

I used the minimum stopover length - the number of days between the first capture and the last recapture of an individual - as an estimate for true stopover duration (Yosef \& Chernetsov 2005, Polak \& Szewczyk 2007). To calculate the minimum stopover length, I only used the data of the recaptured birds. Also, I examined the stopover duration and the body mass changes by intervals of "10-day periods" to learn the changes of these items. Differences among stopover duration in subsequent periods were tested using Kruskal-Wallis test. Intervals with less than 10 individuals per species were excluded from my analysis. I estimated the change of body mass during stopover as the percentage of the initial body mass (Yosef \& Chernetsov 2004, Polak \& Szewczyk 2007). To compare the amount of accumulated fat between ringing and recapture, I used the Mann-Whitney U test. I used Spearmans's rank correlation to relate the body mass and fat with the number of days elapsed since the first capture. To test the possible differences in body mass change among the periods, I used one-way ANOVA. Statistical analyses were carried out using Past 3.14 (Hammer et al. 2001).

\section{Results}

\section{Marsh Warbler (Acrocephalus palustris)}

Regular and common breeder and a migratory species. The largest population can be found along the canals, but it also frequently breeds in abandoned gardens and weedy areas. The population density along the Tulkánéri canal can reach two pairs within 100 meters. It has a small population on the Turai lawn, and it is only an occasional breeder in the quarry ponds.

In spring between 2013-2019, I observed the first individuals between 2 May and 10 May (Table 1). During the non-standard ringing, birds migrating through the area were caught between 6-17 May.

The members of the local population disappear from the nesting sites until late July. In some years (e.g. 2019), singing males can be heard even in mid-July.

In autumn, a total of 217 individuals were caught and 48 of these individuals were recaptured $(22.1 \%)$. Of the ringed birds, seven were adult and 210 juveniles $(3.2 \%$ and $96.8 \%)$.

The migration took place between 1 August and 28 September, with a median date of 20 August (Figure 2). There was a significant difference between years, as the median of migration was later in both 2017 and $2018(H=17.06, p=0.0006)$ (Figure 3). Differences in 
Table 1. Spring arrival dates of the study species between 2013-2019 1. táblázat A vizsgált fajok tavaszi visszaérkezési idejei 2013-2019 között

\begin{tabular}{|l|c|c|c|c|c|c|c|}
\hline \multicolumn{1}{|c|}{ Species } & $\mathbf{2 0 1 3}$ & $\mathbf{2 0 1 4}$ & $\mathbf{2 0 1 5}$ & $\mathbf{2 0 1 6}$ & $\mathbf{2 0 1 7}$ & $\mathbf{2 0 1 8}$ & $\mathbf{2 0 1 9}$ \\
\hline Marsh Warbler & 9 May & 9 May & 10 May & 6 May & 7 May & 5 May & 2 May \\
\hline Eurasian Reed Warbler & 16 April & 27 April & 16 April & 12 April & 23 April & 12 April & 18 April \\
\hline Sedge Warbler & 11 April & 8 April & 16 April & 5 April & 10 April & 8 April & 18 April \\
\hline Great Reed Warbler & 23 April & 26 April & 16 April & 18 April & 20 April & 17 April & 24 April \\
\hline Savi's Warbler & 11 April & 8 April & 16 April & 5 April & 10 April & 8 April & 18 April \\
\hline
\end{tabular}

migration between adult and juvenile birds could not be examined due to the low sample size of the adults.

The minimum stopover duration of Marsh Warblers was on average 3.8 days (median = 2 days, range $=1-15$ days, $S D=3.7$ days.)

Concerning stopover duration, significant differences were found between subsequent periods (Kruskal-Wallis test, $H=7.246, p=0.0487$ ) (Figure 4), and their body mass also changed significantly among the periods. The birds captured between 21-30 August have significantly higher body mass than birds captured in any other weeks (one-way ANOVA, F $=5.541, p=0.001)$.

The body mass of recaptured individuals did not change during the stopover at the study area (on average $0.9 \mathrm{~g}, 8.1 \%$ of the initial body mass; $N=24, t=-1.223, p=0.226$ ). In detail, of recaptured birds, $70.8 \%$ showed a body mass gain and $29.2 \%$ showed a body mass loss.

There was a significant correlation between the body mass change and the number of days elapsed between the first capture and the recapture $\left(r_{s}=0.5767, p=0.0025\right)$, i.e. the birds that spent more time in the study area changed their body mass greater.

The amount of fat of the birds at ringing was significantly lower than at recapture (Mann-Whitney U test, $U=1123, z=-2.3734, p=0.017$ ). Changes in fat were higher in parallel with the number of days elapsed between ringing and recapture $\left(r_{s}=0.538, p<0.0001\right)$.

There were also individuals that showed mixed identification characters with the Eurasian Reed Warbler mainly in the color of the plumage, but they were usually distinguishable by biometric parameters. In the first part of the migration period, at the beginning of August, we caught almost exclusively typical birds that were definite by all identification characters. Then, by the second half of the month, these individuals have disappeared, and individuals with mixed characters appeared.

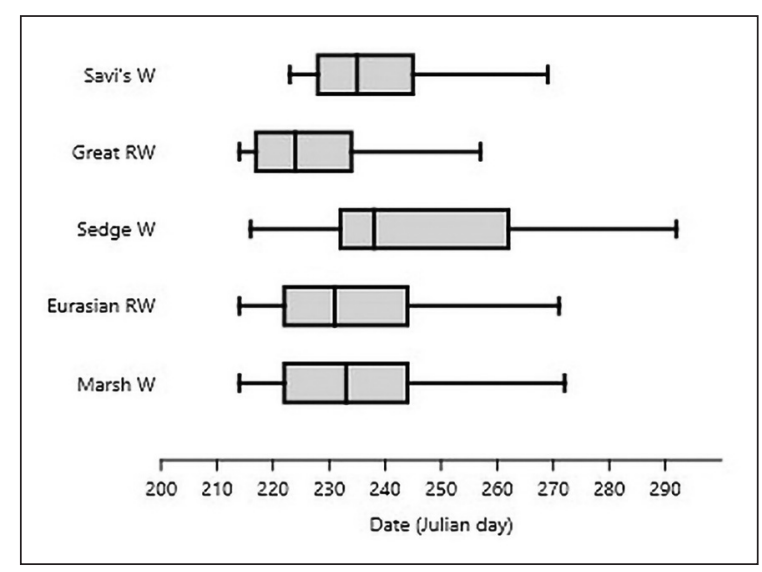

Figure 2. The timing of autumn migration of the study species 2. ábra A vizsgált fajok őszi vonulásának időzítése 


\section{Eurasian Reed Warbler (Acrocephalus scirpaceus)}

Regular, but small number breeder and common migrant. In the study area, a small population of 3-4 pairs regularly breeds in the reedbeds of the Turai lawn. Occasionally, it can be also found as a breeder in the largest reedbed of the Cigányka canal called Jérce lawn.

In spring, I noticed the first singing birds between 12-27 April (Table 1). According to six individuals ringed in the area of the quarry ponds, its migration continues even in mid-May. The first non-local recapture of the species comes also from the spring season. This individual was ringed as a juvenile bird in Farmos (Pest County) on 1 September 2015 and recaptured on 18 May 2016 in the area of the quarry ponds.

Nesting birds typically leave the breeding area by the end of July, but for example, on 7 August 2019, I heard a singing male on the Turai lawn.

In autumn, a total of 122 individuals were ringed and 27 of these individuals were recaptured (22.1\%). Of the ringed birds, two were adults and 120 were juveniles $(1.6 \%$ and $98.4 \%)$.

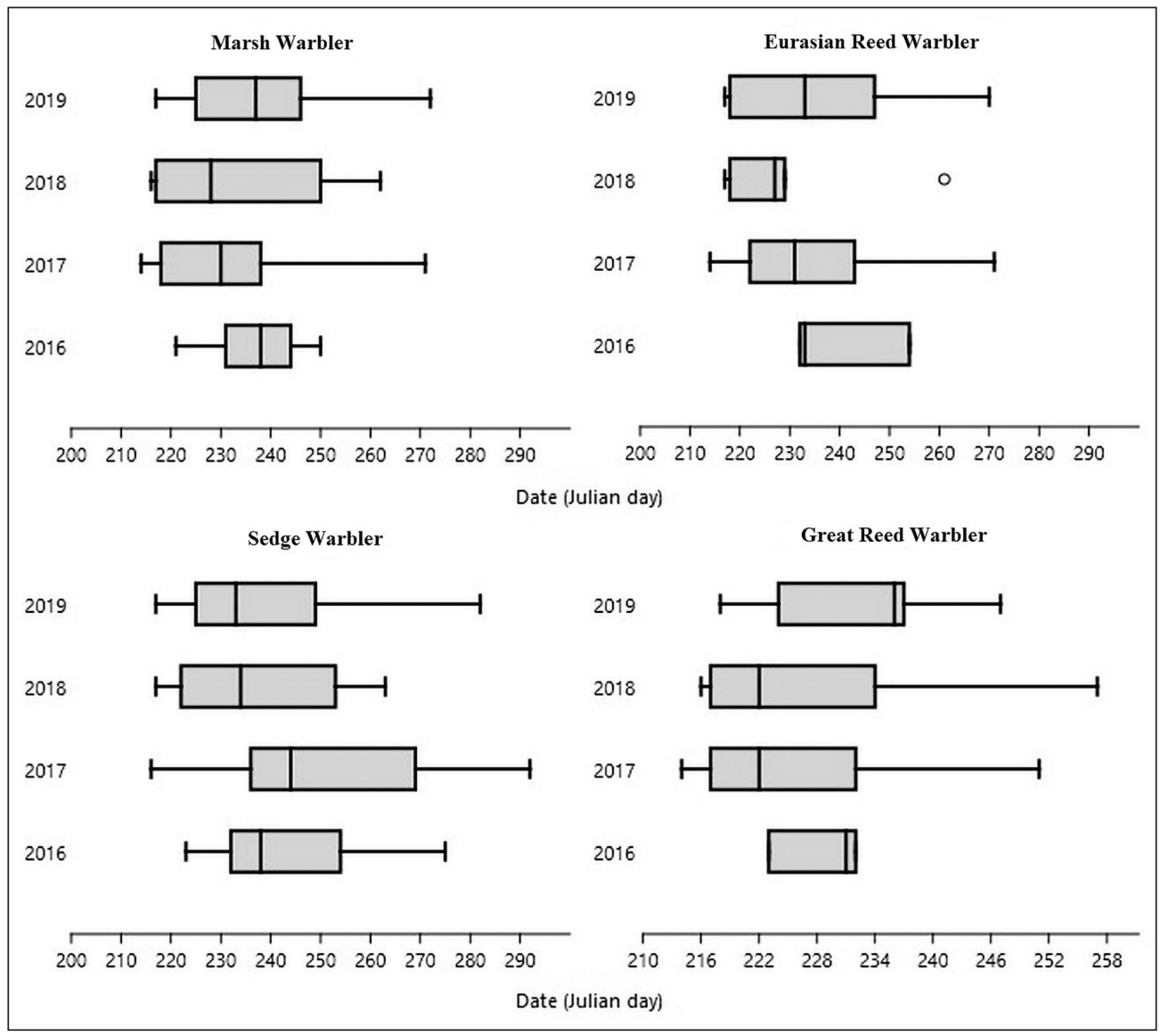

Figure 3. The differences in autumn migration timing between years

3. ábra A vizsgált fajok őszi vonulási időzítésének évenkénti összehasonlítása 
The migration took place between 1 August and 27 September, with a median date on 18 August (Figure 2). The latest data is from 27 September 2017. There were no significant differences among years $(H=3.714, p=0.293)$ (Figure 3). Differences in migration between adult and juvenile birds could not be examined due to the low sample size of the adults.

The minimum stopover duration of Eurasian Reed Warblers was on average 3.1 days (median $=2$ days, range $=1-14$ days, $S D=3.1$ days .

Concerning stopover duration, no significant differences were found between subsequent periods (Kruskal-Wallis test, $H=2.184, p=0.6377$ ), however, their body mass did not change significantly between the periods (one-way ANOVA, $F=1.649, p=0.1687$ ) (Figure 4).

The body mass of recaptured individuals did not change during the stopover at the study area (on average $0.4 \mathrm{~g}, 10.1 \%$ of the initial body mass; $N=14, t=-0.3942, p=0.696$ ). In detail, of recaptured birds, $42.9 \%$ showed a body mass gain, and $57.1 \%$ showed a body mass loss.

There was no significant correlation between the body mass change and the number of days elapsed between the first capture and the recapture $\left(r_{s}=0.4296, p=0.1252\right)$.

The amount of fat of the birds did not change significantly between the first capture and the recapture (Mann-Whitney $U$ test, $U=399.5, z=-1.1551, p=0.248$ ). Changes in fat

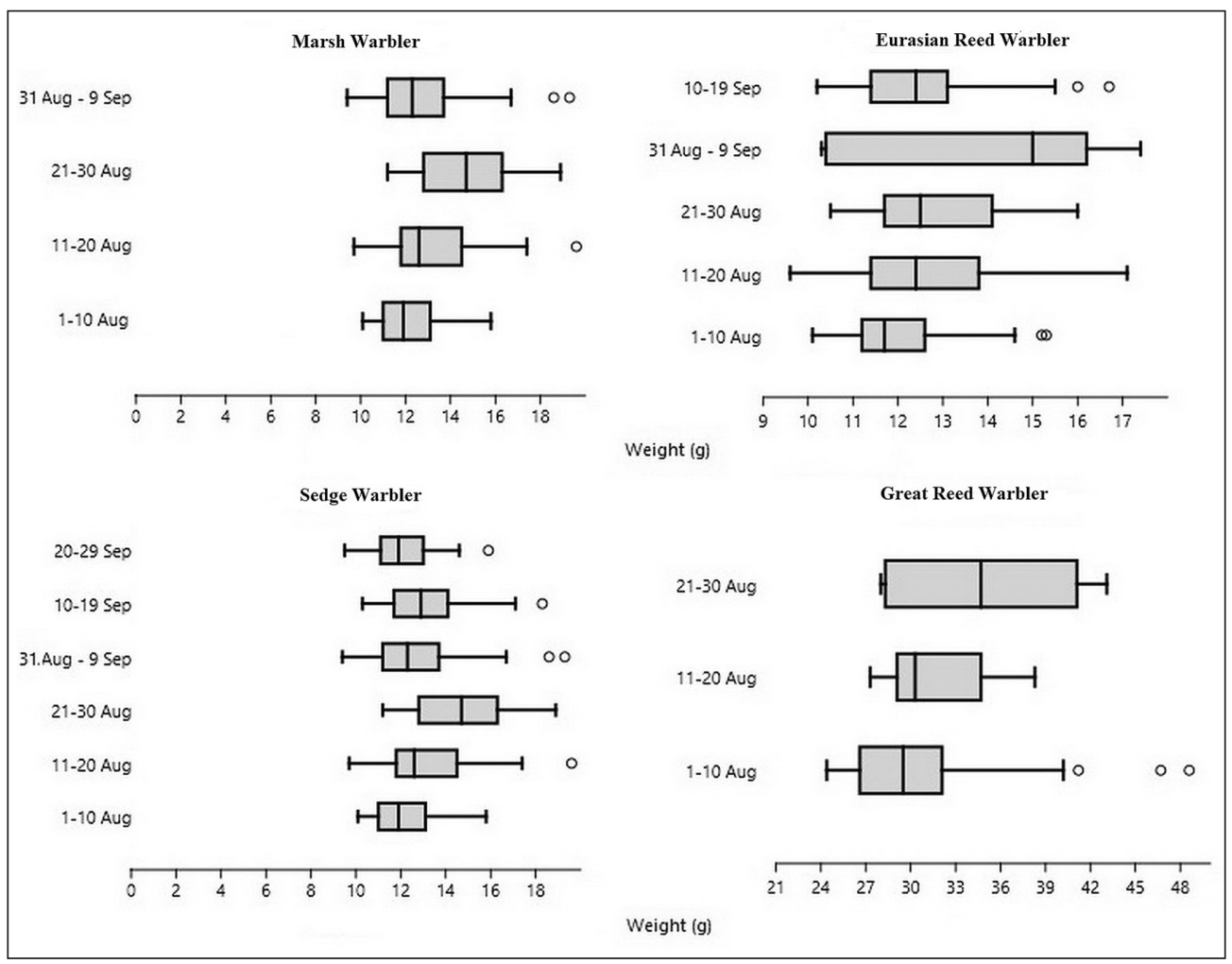

Figure 4. The body mass change of the study species between decades

4. ábra A vizsgált fajok testtömeg-változása dekádonként 
were greater in parallel with the days elapsed between ringing and recapture $\left(r_{s}=0.475, p\right.$ $=0.007$ ).

The second non-local recapture was from the autumn period. A juvenile bird ringed in Komárom-Esztergom County on 6 August 2017 was recaptured on 30 August 2017.

\section{Sedge Warbler (Acrocephalus schoenobaenus)}

This is the most numerous breeding and migratory species among all studied species. The highest population (app. 25-30 pairs) breed in the reedbeds of the Turai lawn. Some pairs can also be found regularly along the canals in smaller reedbeds. Occasionally breeds in grasslands, and in agricultural lands mixed with johnson grass Sorghum halepense and reed. The population of the Turai lawn was stable, with the exception of 2017, when the population decreased to 15 pairs.

In spring, the first singing individuals were observed between 5-18 April (Table 1). My last observation in the quarry ponds was on 8 May, but between the second part of April and early May, it was a regular migrant.

Breeding typically ends by the middle of July, after feeding the young individuals until early in the month (rarely in the middle of the month) and leaving the nesting areas around 20 July. However, 2019 was an extraordinary year due to the significant rainfall in the summer and birds could be observed while feeding the nestlings even in early August (Bozó 2020).

In autumn, a total of 293 individuals were ringed and 20 of these individuals were recaptured (6.8\%). Of the ringed birds, 51 were adults and 242 juveniles $(17.4 \%$ and $82.6 \%)$.

The migration took place between 1 August and 17 October with a median date on $25 \mathrm{Au}-$ gust (Figure 2). The latest data is from 17 October 2017. There was a significant difference among the years (Kruskal-Wallis test, $H=14.29, p=0.0025)$ (Figure 3). Adults migrated significantly earlier than juveniles (Kruskal-Wallis test, $H=12.68, p=0.0003$, median adults: 24 August, median juveniles: 31 August).

The minimum stopover duration of Sedge Warblers was on average 2.6 days (median $=1$ day, range $=1-8$ days, $S D=2.6$ days).

Concerning stopover duration, no significant differences were found (Kruskal-Wallis test, $H=1.88, p=0.5814$ ). Their body mass changed significantly between the periods (one-way ANOVA, $F=5.11, p<0.0001)$.

The body mass of recaptured individuals did not change during the stopover at the study area (on average $0.9 \mathrm{~g}, 6.3 \%$ of the initial body mass, $t=-0.6370, p=0.5343$ ) (Figure 4). In detail, of recaptured birds, $50 \%$ showed a body mass gain, and $50 \%$ showed a body mass loss.

There was a significant correlation between the body mass change and the number of days elapsed between the first capture and the recapture $\left(r_{s}=0.7864, p=0.0333\right)$, i.e. the birds that spent more time in the study area changed their body mass greater.

The amount of fat of the birds did not change significantly between the first capture and the last recapture (Mann-Whitney $U$ test, $U=285.5, z=-0.5257, p=0.599$ ). Changes in fat were higher in parallel with the number of days elapsed between ringing and recapture $\left(r_{s}\right.$ $=0.611, p=0.001)$. 


\section{Great Reed Warbler (Acrocephalus arundinaceus)}

The Great Reed Warbler is the second most common breeder among the studied species in the study area. The largest population breeds in the reedbeds of the quarry ponds. In addition, it is also common breeder along the canals (app. 2 pairs/100 meters along the Cigányka canal) as well as in the villages. However, it is a rare breeder in the Turai lawn with a total population of 8-10 pairs. There have been no fluctuations in the species' population over the past decade.

In spring, the first singing birds were observed between 16-26 April (Table 1). The data of non-standard ringing revealed that some individuals migrate even in mid-May.

Breeding typically ends by the second half of July. The latest observation regarding adults feeding nestlings was on 21 July 2014.

In autumn, a total of 65 individuals were ringed and 18 of these individuals were recaptured (27.7\%). Of the ringed birds, seven were adult and 58 juveniles (10.8\% and 89.2\%).

Migration took place between 1 August and 13 September with a median date on $11 \mathrm{Au}-$ gust (Figure 2). The latest data is from 13 September 2018. There were no significant differences among the years (Kruskal-Wallis test, $H=7.41, p=0.0587$ ) (Figure 3). Differences in migration between adult and juvenile birds could not be examined due to the low sample size of the adults.

The minimum stopover duration of Great Reed Warblers was on average 3.4 days (median $=1$ day, range $=1-18$ days, $S D=4.2$ days .

Concerning stopover duration, no significant differences were found between subsequent periods (Kruskal-Wallis test, $H=0.2858, p=0.84$ ). Their body mass did not change significantly between the periods (one-way ANOVA, $F=1.793, p=0.1772$ ) (Figure 4).

The body mass of recaptured individuals did not change during the stopover at the study area (on average $1.1 \mathrm{~g}, 3.1 \%$ of the initial body mass, $t=-0.751, p=0.4662$ ). In detail, of recaptured birds, $35.7 \%$ showed a body mass gain, and $64.3 \%$ showed a body mass loss.

There was a significant correlation between the body mass change and the number of days that elapsed between the first capture and the recapture $\left(r_{s}=0.6203, p=0.018\right)$, i.e. the birds that spent more time in the study area changed their body mass greater.

The body mass of recaptured individuals did not change during the stopover at the study area (Mann-Whitney U test, $U=111.5, z=-0.021, p=0.983$ ). There was no correlation between the change of fat amount and the number of days elapsed between the first capture and the recapture $\left(r_{s}=0.128, p=0.649\right)$.

It should be noted that an individual was seen on 2 October 2013 on the field, which is the latest occurrence of the species in the study area.

\section{Savi's Warbler (Locustella luscinioides)}

Regularly breeds and migrates through the area in small number. The only place where the species regularly breeds is the Turai lawn. In 2014, the pairs bred in the reedbed of the Tulkán law and the Jérce lawn.

The first singing birds were observed between 5-18 April (Table 1). I do not have information on its spring migration due to the lack of ringing data. 
The nesting pairs are on the breeding ground until mid-July, however, it is not uncommon that the adults feed the nestlings in this period. They typically disappear from the area by the end of the month. However, 2019 was an exception, as on 7 August, I observed nestlings fed by the parents, and even on 11 September, I observed specimens moving in the area.

In autumn, a total of eight individuals were ringed and two of these individuals were recaptured $(25 \%)$.

The migration took place between 10 August and 25 September with a median date on 22 August (Figure 2). The latest data is from 25 September 2017.

Both recaptured individuals were caught two times after ringing (five and thirteen, and one and seven days elapsed between the ringing and the recaptures).

\section{Discussion}

Among the bird species examined in my study, the local nesting populations of Sedge Warbler, Marsh Warbler and Great Reed Warbler were proportional to the number of captured individuals during the autumn migration. This can be compared with the assertion that the number of birds in a given resting and feeding place during the migration season correlates significantly with the size of the local breeding population (Safriel \& Lavee 1991). In this case, it can be interpreted as the number of birds trapped in the canal and oleaster forest in autumn is in parallel with their breeding population in the region. However, in the case of the Eurasian Reed Warbler, which has the smallest local breeding population, we caught far more birds than we should have by this logic. The reason for this is probably the fact that the canal plays an important role in the migration of the species, it is a migration corridor, so the individuals of the more distant populations migrate here. This was also assumed for other species migrating mainly during daytime by Bozó et al. (2017) and Schupkégel et al. (under revision).

The relative lack of Eurasian Reed Warbler in the landscape also makes it likely that individuals with mixed phenological characters can arrive from further geographic regions. The two species can hybridize only in habitats where they breed close to each other (Lemaire 1977). The Marsh Warbler breeds mainly in the edges of reedbeds, along canals and other weedy plant communities (Csörgö 1998b, Végvári 2008a, Haraszthy 2019), while the Eurasian Reed Warbler breeds in the larger, more closed reedbeds (Csörgö 1998c, Végvári 2008b, Haraszthy 2019). Individuals with mixed characters tend to occur later in the migratory period, whereas in early-August, I trapped birds with almost typical, clear, species-specific characters.

There are similarities and differences in the timing of the autumn migration of the five species. The earliest species was the Great Reed Warbler, followed by the Marsh and Eurasian Reed Warbler, while the latest species was the Sedge Warbler. This is similar to the one described by Gyurácz and Csörgő (1991) in Ócsa and Sumony. The lengths of migration periods are also similar to those: the shortest for Great Reed Warbler, followed by Marsh Warbler and Common Reed Warbler, while the Sedge Warbler has the longest migration period. This is probably due to the fact that the Sedge Warbler has a much larger and more northern distribution area than other species (BirdLife International 2020), so the birds reach and migrate 
through the Carpathian Basin, which is an important resting place, in wider intervals (Csörgö \& Gyurácz 2009a).

The median date of migration of the Marsh Warbler was on 20 August. This coincides with the date when $90 \%$ of the birds in Ócsa left the area (Gyurácz \& Csörgő 1991). In the Carpathian Basin, the peak of the species' migration is at the end of July and beginning of August (Csörgö \& Gyurácz 2009b), that is three weeks before the median date of the migration of the birds in my study site. One of the reasons for this difference might be that in the Actio Hungarica camps they started ringing in mid-July, two weeks before the work started in Kevermes. However, this does not explain the three-week difference, because in the beginning of August we would have had to catch a much larger number of the Marsh Warblers. It should be noted, that there was ringing every day in the Actio Hungarica camps, and only two days a week in the present study, therefore this may also skew the results of any comparisons. There is also a possibility that local agricultural areas are less suitable for the breeding of the species than natural habitats, and that is why I trapped mainly migrating birds from northern populations. The migration dynamics of birds with mixed characters also seems to support this.

However, in the case of Eurasian Reed Warbler, comparisons with data from the Carpathian Basin are likely to be made, as the migration begins later than that of the Marsh Warbler (Csörgö \& Gyurácz 2009c). According to the results, this species seems to migrate later in the region than in Ócsa and Sumony, probably for the same reason as the Marsh Warbler. Because of the absence of suitable habitats, the species do not breed in large numbers in the region, thus their number only increases with the arrival of individuals of further populations. Also, it should be emphasized, that the northern populations migrate through the Carpathian Basin only in small numbers (Csörgö \& Gyurácz 2009c), so the birds I trapped in mid-August may have come from within the Carpathian Basin. This may be supported by the fact that the species is very rare in the second half of September and has no data at all in October, although it occurs in Hungary by mid-October (Csörgö \& Gyurácz 2009c). Based on the two long-term recaptures, the birds follow the southeast-northwest direction, which is similar to the birds breeding in or migrating through the Carpathian Basin (Gyurácz et al. 2004).

The median date of migration of Sedge Warbler was on 25 August. In Ócsa, this was on 17 August, in Fenékpuszta on 19 August, and in Sumony on 16 August (Gyurácz \& Csörgö 1994). The difference is probably due to the differences in the start of the work and the number of working days of these locations and may ringing station. The same might be true for the Great Reed Warbler, where the difference is similar (Csörgő \& Gyurácz 2009d). The migration of adult birds peaked a week earlier than that of juveniles, which is similar to data published from different places in Hungary (Gyurácz \& Csörgő 1991, Gyurácz \& Bank 1997, Csörgő \& Gyurácz 2009d).

The migration of the Savi's Warbler was studied in Sumony, Southern Hungary between 1993-2002 (Mátrai et al. 2006). Their results show that the migration of the species falls in late July and early August, but there were still migratory individuals in September and early October. Based on biometric data, two migration waves were identified with a border line on 16 August. The individuals migrating in the second wave had longer wings, so they may have come from more northern populations. As only a few specimens were ringed in the autumn during my study, I do not have accurate information on the autumn migration of the species, 
but based on Mátrai et al. (2006) and the typical ringing time after mid-August, it is likely that the majority of birds come from more northern areas. The peak period of the spring migration in Hungary is in mid-April, and the last local birds arrive in the first days of May (Gyurácz \& Csörgö 2009). This is also similar to my results.

However, when dealing with migration phenology when comparing studies covering longer time periods, the effects of climate change should not be forgotten either. As a result of ringing in Ócsa between 1987-2004, it was found that the migration of the Savi's Warbler shifted earlier in the fall, while the migration of the other species I studied shifted later over the decades (Miholcsa et al. 2009). They also found a significant difference between the different age groups in case of Marsh Warbler: adults migrated earlier, while migrated later in the study area. Also, studies in Ócsa between 1989-2009 showed one- or two-week delay for Eurasian Reed Warbler, Marsh Warbler and Sedge Warbler in autumn, while in spring, Eurasian Reed and Sedge Warbler returned 6.5 and 7.5 days earlier in the end of this period (Kovács et al. 2012). In this regard, no significant change in the timing of the spring migration was found for Marsh Warbler. These results call attention to the fact that the results of articles on migration phenology published a few years or decades ago can be used with caution when evaluating the results of recent researches.

Among the species studied, the Sedge Warbler spent the shortest time in the area. In addition to this, there were far fewer recaptures than in the case of the other species. The reason for this phenomenon is that the Sedge Warbler migrates faster than other species and therefore spends less time on other stopover sites (Csörgő \& Gyurácz 2009a). It usually migrates with high fat reserves, but only a minority of birds resting in the Carpathian Basin increase their fat reserves (Csörgő \& Gyurácz 2009a). This is supported by my results as neither the body weight of the birds nor the body fat category changed significantly during the time spent here.

The Marsh Warbler had the most fat reserves of all the species studied, and body fat values also increased during the stopover. All of this is related to the fact that the species flies through larger barriers such as mountains, and therefore accumulates high fat reserves (Csörgö et al. 2000, Csörgő \& Gyurácz 2009a). Conversely, the Eurasian Reed Warbler crossed the area with very little stored fat and did not increase its reserves significantly during its stay. The reason for the low fat reserves is that the species migrates in short steps and use the large Mediterranean peninsulas, so it does not need much fat reserve (Csörgő \& Gyurácz 2009c).

The ringed Great Reed Warblers, however, had higher fat reserves, though they did not increase these fat reserves during the stopover. With regard to the stopover duration, the individuals of the Marsh Warbler spent more in the area over time during the migratory season, while in the case of the other species, there was no change in this respect. This may be because Marsh Warblers have the highest fat reserves and they increase this during their stay. However, as time passes, the amount of available food may decrease due to degradation of herbaceous vegetation and therefore, the birds require more time to accumulate sufficient amounts of fat. Similar to the Marsh Warbler, the Sedge Warbler had a higher body weight at the end of the migratory period than at the beginning. The body weight of both species was highest in the end of August during the migration peak. All this can clearly be related to the assumption that the birds leave with the greatest possible reserves. The migration peak will be when most birds are able to reach critical mass. For the other two species, there was no difference in this 
respect. The Marsh Warbler migrates with much less fat and its amount does not change during the whole migration period. The Eurasian Reed Warbler, however, moves in such a concentrated, narrow period that it cannot develop different fat accumulation strategies.

The earliest spring migrant is the Sedge Warbler followed by the Marsh Warbler, Savi's Warbler and Great Reed-warbler in mid-April. The Marsh Warblers return to the breeding grounds the latest. The reason for the temporal differentiation is the different nesting sites. The first four species breed in reedbeds (Csörgö 2009b, 2009c, 2009d, 2009e, Végvári 2008b, 2008c, 2008d, 2008e, Haraszthy 2019), whilst the Marsh Warblers build their nest in the herbaceous vegetation (Csörgö 1998a, Haraszthy 2019). However, herbaceous plants reach their proper height and density much later than reeds (Csörgö \& Gyurácz 2009b), so birds need to arrive later. It is clear from some spring ringing and field observation data that while some of the local birds are already in the territories, other birds are still migrating. My assumed migration periods for each species overlap with those described in the literature (Csörgő \& Gyurácz 2009a, 2009b, 2009c, 2009d, Gyurácz \& Csörgő 2009).

Overall, reedbeds in secondary habitats play a similar role in the migration and nesting of the most common passerines of this habitat in the southeastern part of Hungary as the natural habitats of other areas in the Carpathian Basin. This is particularly important because, for example, in the case of the European Robin Erithacus rubecula, Gyimóthy et al. (2011) found that the species used different migration strategies in optimal and suboptimal habitats in terms of feeding and resting. The studies were carried out by comparing data from several different ringing station in the Carpathian Basin highlighted that using the data from only one habitat in a migration dynamics study is not enough because the data are influenced by the geographical location and vegetation structure of the area. Studies in the coast of Baltic Sea also support that Eurasian Reed Warblers spend much more time in the optimal habitats (reedbeds) than in shrubs in coastal dunes, and have to devote less energy to obtaining food than in suboptimal habitats (Ktitorov et al. 2010). All these highlight the important shortcoming that the results of Hungarian researches are based almost exclusively on data from natural habitats, so they do not necessarily give a realistic picture of the migratory characteristics of these species in Hungary. More comparative research would be needed between the optimal and suboptimal habitats. The species-specific differences show that due to the limited number of suitable breeding sites available in the area, migrating individuals are from further geographical areas. As emphasized in other works (Bozó et al. 2017, Bozó 2018, Schupkégel et al. under revision), these secondary habitats play a key role in the migration of birds through the agricultural landscape, and their conservation and protection, on at least a local level, are important tasks. This is particularly important because the diversity and bird populations of agricultural areas are rapidly declining across Europe (Chamberlain \& Fuller 2000, Donald et al. 2006), so secondary habitats may be very important in the conservation of certain species.

\section{Acknowledgements}

I am grateful to Tibor Csörgö for his helpful comments on the early version of the manuscript. I am also grateful to Nikolett Olajos for checking and improving the English language of the text. 


\section{References}

Báldi, A. \& Kisbenedek, T. 1999. Species-specific distribution of reed-nesting passerine birds across reed-bed edges: effects of spatial scale and edge type. - Acta Zoologica Academiae Scientiarum Hungaricae 45(2): 97-114.

BirdLife International 2020. IUCN Red List for birds. - http://www.birdlife.org on 13/03/2020.

Bíró, I. 2007. Biharugrai-halastavak [Biharugra fishponds]. - In: Tardy, J. (ed.) A magyarországi vadvizek világa [The wildlife of Hungarian wetland habitats]. - Alexandra Kiadó, Pécs (in Hungarian)

Bozó, L. 2016. A madárgyürüzés eredményei a kevermesi sóderbánya területén 2012-2016 között [Results of bird ringing at the querry ponds in Kevermes between 2012-2016]. - A Száraz-ér társaság kutatásai 2011-2015 között, pp. 35-38. (in Hungarian)

Bozó, L. 2017. Kevermes madárvilága [Birds of Kevermes]. - Dél-békési Természetvédelmi és Madártani Egyesület, Kevermes (in Hungarian with English Summary)

Bozó, L. 2018. Dél-Békés természeti értékei [Nature assets of South-Békés]. - Dél-békési Természetvédelmi és Madártani Egyesület, Kevermes (in Hungarian)

Bozó, L. 2020. A szélsőséges időjárás hatása a madarak fészkelésére [The impact of the extreme weather conditions on the breeding of some bird species]. - Madártávlat 27(1): 29. (in Hungarian)

Bozó, L., Bozóné Borbáth, E. \& Tar, L. 2017. Énekesmadarak őszi vonulása csatornaparti fasoron [Songbird migration in a channel-sided alley]. - Természetvédelmi Közlemények 23: 1-13. DOI: 10.20332/tvk-jnatconserv.2017.23.1 (in Hungarian with English Summary)

Chamberlain, D. E. \& Fuller, R. J. 2000. Local extinctions and changes in species richness of lowland farmland birds in England and Wales in relation to recent changes in agricultural land-use. - Agriculture, Ecosystems \& Environment 78(1): 1-17. DOI: 10.1016/S0167-8809(99)00105-X

Csörgő, T. 1995. A nádas zonációk és szegélyvegetációk énekesmadarai [Niche segregation and microhabitat preference of warblers within a reed stand]. - In: Vásárhelyi, T. (ed.) A nádasok állatvilága [The animals of reed beds in Hungary]. - Magyar Természettudományi Múzeum, Budapest, pp. 138-143. (in Hungarian with English Summary)

Csörgő, T. 1998a Nádirigó [Great Reed-warbler]. - In: Haraszthy, L. (ed.) Magyarország madarai [Birds of Hungary]. - Mezőgazda Kiadó, Budapest, pp. 306-307. (in Hungarian)

Csörgő, T. 1998b Énekes nádiposzáta [Marsh Warbler]. - In: Haraszthy, L. (ed.) Magyarország madarai [Birds of Hungary]. - Mezőgazda Kiadó, Budapest, p. 304. (in Hungarian)

Csörgő, T. 1998c Cserregő nádiposzáta [Eurasian Reed Warbler]. - In: Haraszthy, L. (ed.) Magyarország madarai [Birds of Hungary]. - Mezögazda Kiadó, Budapest, p. 305. (in Hungarian)

Csörgö, T. 1998d Nádi tücsökmadár [Savi’s Warbler]. - In: Haraszthy, L. (ed.) Magyarország madarai [Birds of Hungary]. - Mezőgazda Kiadó, Budapest, p. 299. (in Hungarian)

Csörgő, T. 1998e Foltos nádiposzáta [Sedge Warbler]. - In: Haraszthy, L. (ed.) Magyarország madarai [Birds of Hungary]. - Mezőgazda Kiadó, Budapest, pp. 302-303. (in Hungarian)

Csörgő, T., Karcza, Zs. \& Palkó, S. 1998. Környezeti változások monitorozása énekesmadarakkal [Monitoring of environmental changes with passerine birds]. - Ornis Hungarica 8(Suppl. 1): 17-26. (in Hungarian with English Summary)

Csörgö, T., Miklay, Gy. \& Halmos, G. 2000. Migration of Acrocephalus species along the coast of the Black Sea. - Ornis Hungarica 10: 141-147.

Csörgő, T. \& Gyurácz, J. 2009a Foltos nádiposzáta [Sedge Warbler]. - In: Csörgö, T., Karcza, Zs., Halmos, G., Magyar, G., Gyurácz, J., Szép, T., Bankovics, A., Schmidt, A. \& Schmidt, E. (eds.) Magyar madárvonulási atlasz [Hungarian Bird Migration Atlas]. - Kossuth Kiadó Zrt., Budapest, pp. 483-488. (in Hungarian with English Summary)

Csörgő, T. \& Gyurácz, J. 2009b Énekes nádiposzáta [Marsh Warbler]. - In: Csörgő, T., Karcza, Zs., Halmos, G., Magyar, G., Gyurácz, J., Szép, T., Bankovics, A., Schmidt, A. \& Schmidt, E. (eds.) Magyar madárvonulási atlasz [Hungarian Bird Migration Atlas]. - Kossuth Kiadó Zrt., Budapest, pp. 494-496. (in Hungarian with English Summary)

Csörgő, T. \& Gyurácz, J. 2009c Cserregő nádiposzáta [Eurasian Reed Warbler]. - In: Csörgő, T., Karcza, Zs., Halmos, G., Magyar, G., Gyurácz, J., Szép, T., Bankovics, A., Schmidt, A. \& Schmidt, E. (eds.) Magyar madárvonulási atlasz [Hungarian Bird Migration Atlas]. - Kossuth Kiadó Zrt., Budapest, pp. 489-493. (in Hungarian with English Summary)

Csörgő, T. \& Gyurácz, J. 2009d Nádirigó [Great Reed-warbler]. - In: Csörgő, T., Karcza, Zs., Halmos, G., Magyar, G., Gyurácz, J., Szép, T., Bankovics, A., Schmidt, A. \& Schmidt, E. (eds.) Magyar madárvonulási atlasz 
[Hungarian Bird Migration Atlas]. - Kossuth Kiadó Zrt., Budapest, pp. 499-501. (in Hungarian with English Summary)

Czikkelyné Ágh, N. 2014. Nádiposzáta fajok őszi vonulásának kor-és ivarfüggő mintázatai [Age and sex related autumn migration phenology of the Reed, Marsh and Sedge Warbler]. - Szakdolgozat, Szent István Egyetem, Állatorvos-tudományi Kar Biomatematikai és Számítástechnikai Tanszék, Biológiai Intézet (in Hungarian)

Donald, P. F., Sanderson, F. J., Burfield, I. J. \& Van Bommel, F. P. 2006. Further evidence of continent-wide impacts of agricultural intensification on European farmland birds, 1990-2000. - Agriculture, Ecosystems \& Environment 116(3-4): 189-196. DOI: 10.1016/j.agee.2006.02.007

Eck, S., Fiebig, J., Fiedler, W., Heynen, I., Nicolai, B., Töpfer, T., van den Elzen, R., Winkler, R. \& Woog, F. 2011. Vögel vermessen/measuring birds. - Deutsche Ornithologen-Gesellschaft, Minden, Christ Media Natur

Gyimóthy, Zs., Gyurácz, J., Bank, L., Bánhidi, P., Farkas, R., Németh, Á. \& Csörgő, T. 2011. Autumn migration of Robins (Erithacus rubecula) in Hungary. - Biologia 66(3): 548-555. DOI: 10.2478/s11756-011-0039-9

Gyurácz, J. \& Csörgö, T. 1991. Az öreg és a fiatal madarak őszi vonulása közti különbségek négy nádiposzáta (Acrocephalus spp.) fajnál [Differences between autumn migration of adult and juvenile birds in four reed warbler (Acrocephalus spp.) species]. - MME III. Tudományos Ülése, Szombathely, pp. 164-171. (in Hungarian with English Summary)

Gyurácz, J. \& Csörgő, T. 1994. Autumn migration dynamics of the Sedge Warbler (Acrocephalus schoenobaenus) in Hungary. - Ornis Hungarica 4: 31-37.

Gyurácz, J. \& Bank, L. 1997. Spatial distribution of migrating Sedge Warblers (Acrocephalus schoenobaenus) in a Hungarian reed bed. - Ornis Hungarica 7: 43-47.

Gyurácz, J., Bank, L. \& Horváth, G. 2004. Studies on the population and migration dynamics of five reed warbler species in a South Hungarian reed bed. - Aquila 111: 105-129.

Gyurácz, J. \& Csörgö, T. 2009. Nádi tücsökmadár [Savi’s Warbler]. - In: Csörgö, T., Karcza, Zs., Halmos, G., Magyar, G., Gyurácz, J., Szép, T., Bankovics, A., Schmidt, A. \& Schmidt, E. (eds.) Magyar madárvonulási atlasz [Hungarian Bird Migration Atlas]. - Kossuth Kiadó Zrt., Budapest, pp. 473-475. (in Hungarian with English Summary)

Gyurácz, J., Horváth, G., Csörgö, T., Bank, L. \& Palkó, S. 2003. Influence of macrosyoptic weather situation on the autumn migration of birds in Hungary. - Ring 25(1-2): 18-20.

Gyurácz, J., Károssy, Cs., Csörgő, T., Bank, L. \& Palkó, S. 1998. A makroszinoptikus időjárási helyzetek hatása a foltos nádiposzáta (Acrocephalus schoenobaenus) őszi vonulásdinamikájára [Influence of the macrosynoptical weather situations on the autumn migration dynamics of the Sedge Warblers (Acrocephalus schoenobaenus)]. - Ornis Hungarica 8(Suppl. 1): 163-168. (in Hungarian with English Summary)

Hammer, Ø., Harper, D. A. \& Ryan, P. D. 2001. PAST: Paleontological statistics software package for education and data analysis. - Palaeontologia Electronica 4(1): 9.

Haraszthy, L. 2013. Értékőrző gazdálkodás Natura 2000 területeken [Farming in Natura 2000 areas]. - Pro Vértes Természetvédelmi Közalapítvány, Csákvár (in Hungarian)

Haraszthy, L. 2019. Magyarország fészkelő madarainak költésbiológiája. 2. kötet. Sárgarigóféléktől a sármányfélékig [Breeding biology of Hungarian nesting birds. Vol. 2. Passeriformes]. - Pro Vértes Nonprofit Kft., Csákvár, pp. 448-453. (in Hungarian)

Jakab, G. \& Deli, T. 2012. A Dél-Tiszántúl természetföldrajzi viszonyai [The natural characteristic of the SouthTiszántúl]. - In: Jakab, G. (ed.) A Körös-Maros Nemzeti Park növényvilága [The Flora of the Körös-Maros National Park]. - Körös-Maros Nemzeti Park Igazgatóság, Szarvas, pp. 24-33. (in Hungarian)

Kovács, Sz., Fehérvári, P., Nagy, K., Harnos, A. \& Csörgö, T. 2012. Changes in migration phenology and biometrical traits of Reed, Marsh and Sedge Warblers. - Central European Journal of Biology 7(1): 115-125. DOI: 10.2478/s11535-011-0101-1

Ktitorov, P., Tsvey, A. \& Mukhin, A. 2010. The good and the bad stopover: behaviours of migrant Reed Warblers at two contrasting sites. - Behavioral Ecology and Sociobiology 64(7): 1135-1143. DOI: 10.1007/s00265010-0929-9

Lemaire, F. 1977. Mixed song, interspecific competition and hybridization in the Reed and Marsh Warblers A. scirpaceus and A. palustris. - Behaviour 3: 215-240.

Mátrai, N., Gyurácz, J. \& Bank, L. 2006. A nádi tücsökmadár (Locustella luscinioides) őszi vonulása egy dél-magyarországi nádasban [Autumn migration of Savi’s Warblers (Locustella luscinioides) in a southern Hungarian reed-bed]. - Állattani Közlemények 91(1): 19-28.

Miholcsa, T., Tóth, A. \& Csörgö, T. 2009. Change of timing of autumn migration in Acrocephalus and Locustella genus. - Acta Zoologica Academiae Scientiarum Hungaricae 55(2): 175-185. 
Nagy, K., Csörgő, T., Harnos, A. \& Kovács, Sz. 2009. A cserregő és az énekes nádiposzáta (Acrocephalus scirpaceus, A. palustris) vonulásának fenológiai változásai [Changes in the migration phenology of Reed and Marsh Warbler (Acrocephalus scirpaceus, A. palustris)]. - Természetvédelmi Közlemények 15: 434-445. (in Hungarian with English Summary)

Polak, M. \& Szewczyk, P. 2007. Relation between stopover length and time and body parameters of European Robin Erithacus rubecula (L., 1758) during autumn migration (Central Poland). - Polish Journal of Ecology 55(3): 511-517.

Preiszner, B. \& Csörgő, T. 2008. Habitat preference of Sylviidae warblers in a fragmented wetland. - Acta Zoologica Academiae Scientiarum Hungaricae 54(Suppl. 1): 111-122.

Safriel, U. N. \& Lavee, D. 1991. Relative abundance of migrants at a stopping-over site and the abundance in their breeding ranges. - Bird Study 38(1): 71-72. DOI: 10.1080/00063659109477069

Schupkégel, B., Bozó, L. \& Tölgyesi, Cs. (under revision). The role of the water canals and secondary forests in bird migration. - Ring

Svensson, L. 1992. Identification guide to European passerines. - Svensson, Stockholm

Vadász, Cs., Németh, Á., Karcza, Zs., Loránt, M., Biró, Cs. \& Csörgő, T. 2008. Study on breeding site fidelity of Acrocephalus warblers in Central Hungary. - Acta Zoologica Hungarica 54(Suppl. 1): 167-175.

Végvári, Zs. 2008a Énekes nádiposzáta [Marsh Warbler]. - In: Hadarics, T. \& Zalai, T. (eds.) Magyarország madarainak névjegyzéke - Nomenclator Avium Hungariae. - Magyar Madártani és Természetvédelmi Egyesület, Budapest, p. 188.

Végvári, Zs. 2008b Cserregő nádiposzáta [Eurasian Reed Warbler]. - In: Hadarics, T. \& Zalai, T. (eds.) Magyarország madarainak névjegyzéke - Nomenclator Avium Hungariae. - Magyar Madártani és Természetvédelmi Egyesület, Budapest, p. 188.

Végvári, Zs. 2008c Nádirigó [Great Reed-warbler]. - In: Hadarics, T. \& Zalai, T. (eds.) Magyarország madarainak névjegyzéke - Nomenclator Avium Hungariae. - Magyar Madártani és Természetvédelmi Egyesület, Budapest, p. 189.

Végvári, Zs. 2008d Nádi tücsökmadár [Savi’s Warbler]. - In: Hadarics, T. \& Zalai, T. (eds.) Magyarország madarainak névjegyzéke - Nomenclator Avium Hungariae. - Magyar Madártani és Természetvédelmi Egyesület, Budapest, p. 186.

Végvári, Zs. 2008e Foltos nádiposzáta [Sedge Warbler]. - In: Hadarics, T. \& Zalai, T. (eds.) Magyarország madarainak névjegyzéke - Nomenclator Avium Hungariae. - Magyar Madártani és Természetvédelmi Egyesület, Budapest, p. 187.

Yosef, R. \& Chernetsov, N. 2005. Longer is fatter: body mass changes of migrant Reed Warblers (Acrocephalus scirpaceus) staging at Eilat, Israel. - Ostrich 76(3-4): 142-147. DOI: 10.2989/00306520509485486

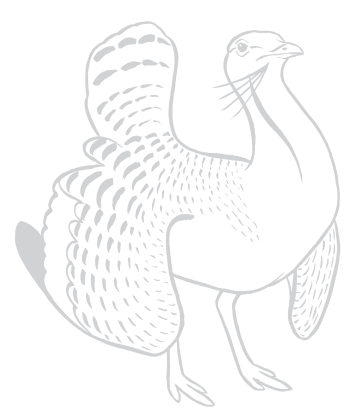

